\title{
Mechanism of stabilization of dicalcium silicate solid solution with aluminium
}

\author{
Ana Cuesta ${ }^{\mathrm{a}}$, Miguel A. G. Aranda ${ }^{\mathrm{a}, \mathrm{b}}$, Jesús Sanz ${ }^{\mathrm{c}}$, Ángeles G. de la Torre ${ }^{\mathrm{a}}$, Enrique R. Losilla ${ }^{\text {* }}$ \\ ${ }^{a}$ Departamento de Química Inorgánica, Cristalografía y Mineralogía, Universidad de Málaga, \\ 29071-Málaga, Spain. \\ ${ }^{\mathrm{b}}$ CELLS-ALBA Synchrotron, Carretera BP 1413, Km. 3.3, E-08290 Cerdanyola, Barcelona, Spain \\ ${ }^{\mathrm{c}}$ Instituto de Ciencia de Materiales de Madrid (ICMM), Consejo Superior de Investigaciones \\ Científicas (CSIC), Cantoblanco, 28049-Madrid, Spain
}

* Corresponding author: Dr. Enrique R. Losilla, r_losilla@uma.es, Telephone: +34-952134234, Fax: +34-952137534

KEYWORDS: PC-SOFC, Mixed oxide and proton conductor, aluminum doped dicalcium silicate

\section{ABSTRACT:}

Stoichiometric dicalcium silicate, $\mathrm{Ca}_{2} \mathrm{SiO}_{4}$, displays a well-known polymorphism with temperature. When this phase is doped by a range of elements generates belite, one of the main phases of cements. Here, we thoroughly study the aluminum doping of dicalcium silicate. This type of study is important for cement characterization and also from a basic point of view. $\mathrm{Ca}_{2} \mathrm{Si}_{1-2 \mathrm{x}} \mathrm{Al}_{2 \mathrm{x}} \mathrm{O}_{4-\mathrm{x}} \square_{\mathrm{x}}$ $(\mathrm{x}=0,0.010,0.014,0.03$. $)$ has been prepared and studied by $\mathrm{X}$-ray powder diffraction and the Rietveld method. The limiting composition has been established as $\mathrm{Ca}_{2} \mathrm{Si}_{0.972} \mathrm{Al}_{0.028} \mathrm{O}_{3.986} \square_{0.014}{ }^{27} \mathrm{Al}$ MAS NMR band located close to $\sim-70 \mathrm{ppm}$ is ascribed to tetrahedral environments, in agreement with the proposed alivalent $\mathrm{Si} / \mathrm{Al}$ atomic substitution mechanism. Thermal analysis measurements in a wet atmosphere indirectly confirm the increase of oxygen vacancies as the amount of incorporated protons increases with the aluminium content. A thorough electrical characterization has been carried out including overall conductivity measurements in wet and dried atmospheres and conductivity as a function of the oxygen partial pressure. The samples show oxide anion conductivity with a small p-type electronic contribution under oxidizing conditions. These compounds display a very important proton contribution to the overall conductivities under humidified atmospheres. 


\section{Introduction}

Oxides that exhibit significant proton conductivity at elevated temperatures are candidates for different electrochemical applications, such as hydrogen sensors, membranes for hydrogen production and proton conducting solid oxide fuel cells (PC-SOFC). ${ }^{1-5}$ The most studied ceramic proton conductors are those based on cerates $\mathrm{BaCeO}_{3}$ and zirconates $\mathrm{BaZrO}_{3}$ with perovskite type structure $\left(\mathrm{ABO}_{3}\right)$. Oxygen vacancies are introduced into the perovskite structure by aliovalent doping, i.e. partial replacement of cerium or zirconium by $\mathrm{Y}^{3+}, \mathrm{Yb}^{3+}, \mathrm{Gd}^{3+}, \mathrm{Nd}^{3+}$, etc. ${ }^{6-12}$ The proton conduction in these materials occurs either via the hydration of oxygen vacancies after the material is exposed to water-containing atmospheres (Ec. 1) and/or by reduction of oxide ions in the lattice (Ec. 2).

$$
\begin{array}{ll}
\mathrm{H}_{2} \mathrm{O}(\mathrm{g})+\mathrm{O}_{O}^{x}+\mathrm{v}_{O}^{\ddot{*}}=2 \mathrm{OH}_{O}^{\bullet} & \text { (Ec. 1) } \\
\mathrm{H}_{2}(\mathrm{~g})+2 \mathrm{O}_{O}^{x}=2 \mathrm{OH}_{O}^{\bullet}+2 \mathrm{e}^{\prime} & \text { (Ec. 2) }
\end{array}
$$

As part of the efforts to find suitable alternate electrolyte materials for PC-SOFCs, we have reported a new family of oxide ion conductors based on tricalcium oxy-silicate. ${ }^{13,14} \mathrm{Ca}_{3} \mathrm{SiO}_{5}$ (alite in cement nomenclature) is the main constituent of ordinary Portland cements (OPC), this phase contains some oxide anions which are only bonded to the calcium atoms forming rows that are the responsible for the oxide conductivity properties. Tricalcium silicate also shows a small p-type electronic contribution under oxidizing conditions and display an important proton contribution under humidified atmosphere. The possibilities of aluminum substitution in the tetrahedral site have been studied ${ }^{14}$, oxygen vacancies can not be stabilized by partial substitution of silicon by aluminum since $\mathrm{Ca}_{3}\left(\mathrm{SiO}_{4}\right)_{1-\mathrm{x}}\left(\mathrm{AlO}_{4}\right)_{\mathrm{x}} \mathrm{O}_{1-\mathrm{x} / 2} \square_{\mathrm{x} / 2}$ series is not formed. The aluminum doping in this system is achieved by substitution at both calcium and silicon sites rendering a fixed oxygen content series: $\mathrm{Ca}_{3-\mathrm{x}} \mathrm{Al}_{\mathrm{x}}\left(\mathrm{SiO}_{4}\right)_{1-\mathrm{x}}\left(\mathrm{AlO}_{4}\right)_{\mathrm{x}} \mathrm{O} \quad 0.0 \leq \mathrm{x} \leq 0.03 .{ }^{14}$ The electrochemical characterization indicates that these compounds are oxide anion conductors with a small contribution of p-type electronic conductivity.

On the other hand, dicalcium silicate, $\mathrm{Ca}_{2} \mathrm{SiO}_{4}$ (belite in cement nomenclature), is the mayor constituent of belite Portland cements and some calcium sulfoaluminate cements. ${ }^{15}$ Furthermore, this phase is commonly the second most abundant constituent of OPC. Stoichiometric $\mathrm{C}_{2} \mathrm{~S}$ exhibits five polymorphs at ordinary pressure ${ }^{16,17}$ when is heated $\left(\gamma, \beta, \alpha_{L}^{\prime}, \alpha_{H}^{\prime}\right.$ and $\left.\alpha\right)$ and its temperature evolution is shown in Figure 1 . The $\beta$-form is a metastable monoclinic phase at room temperature. ${ }^{18}$ The $\gamma$-phase, is stable at ambient temperature and it crystallizes in an orthorhombic olivine-type 
structure $^{19-22}$, but is essentially nonreactive with water. $\alpha_{\mathrm{L}}^{\prime}$ and $\alpha_{\mathrm{H}}^{\prime}$ orthorhombic phases are stable at high temperatures. ${ }^{23}$ It is noteworthy, that $\beta \rightarrow \gamma$ polymorphic transformation on cooling is disruptive with a change of $12 \mathrm{vol} \%$. This effect is called "dusting" as it degrades refractory materials ${ }^{24}$ and can be avoided by chemical, thermal and mechanical treatments. ${ }^{16,25}$ The crystal structures and relative stabilities of the dicalcium silicate polymorphs have been studied from atomistic simulations. ${ }^{26}$ Furthermore, the role of some impurities has also been studied by theoretical tools. ${ }^{27,28}$

The framework of silicon tetrahedra is very similar among these polymorphs, while the arrangement of calcium cations is slightly different. The crystal structure of $\gamma-\mathrm{C}_{2} \mathrm{~S}$ has two calciums in regular six-coordinated oxygen environments. Meanwhile, the crystal structure of $\beta-C_{2} S$ has two calciums surrounded by eight oxygens in distorted environments. Moreover, the crystal structures of $\alpha_{\mathrm{H}^{-}}^{\prime}$ and $\alpha$ - polymorphs have calcium cations in both eight and nine irregular coordination. ${ }^{16,21}$ It is important to know that there are experimental evidences that an increase of the calcium coordination number seems to enhance the water reactivity. ${ }^{29}$ Nevertheless, crystal chemical stabilization is obtained by the addition of suitable "stabilizers" which are responsible of the actual reactivity. ${ }^{16}$

The effects on chemical-stabilizing ions on the stability of $\beta-C_{2} S$ have been extensively investigated, ${ }^{16,30,31}$ and several theoretical predictions have been made about which ions can stabilize $\beta-\mathrm{C}_{2} \mathrm{~S}\left(\mathrm{~B}_{2} \mathrm{O}_{3}, \mathrm{Al}_{2} \mathrm{O}_{3}, \mathrm{Na}_{2} \mathrm{O}, \mathrm{K}_{2} \mathrm{O}, \mathrm{BaO}, \mathrm{MnO}_{2}, \mathrm{Cr}_{2} \mathrm{O}_{3}\right.$ or their combinations). ${ }^{32-37}$ Gao-Chao et $a{ }^{37}$ found that the forming amount of $\beta-\mathrm{C}_{2} \mathrm{~S}$ depended on varieties of dopant ions and the composition stoichiometry in the samples; although these authors did not state the mechanism and the extension of the formed solid solution. The stabilizing ability of the ions varied significantly, and the cations $\mathrm{Al}^{3+}$ were quite effective in stabilizing the $\beta$-phase over a wide range of doping concentrations, i.e. 4-10 mol \%. ${ }^{29,37}$ Recently, we have reported a study of the doping mechanism of $\mathrm{B}$ and $\mathrm{Na} / \mathrm{B}$ in belites. ${ }^{38}$ The experimental results support the substitution of silicate groups by tetrahedral borate groups with the concomitant substitution of calcium by boron for charge compensation, $\mathrm{Ca}_{2-\mathrm{x}} \mathrm{B}_{\mathrm{x}}\left(\mathrm{SiO}_{4}\right)_{1-\mathrm{x}}\left(\mathrm{BO}_{4}\right)_{\mathrm{x}} 0.0 \leq \mathrm{x} \leq 0.10$. This doping mechanism is similar to that already reported for aluminium doping in alite.

The objective of this study is to investigate the mechanism of $\beta$ belite stabilization at room temperature by $\mathrm{Al}_{2} \mathrm{O}_{3}$ and to evaluate the influence of $\mathrm{Al}^{3+}$ substitution in the structure and transport properties of $\mathrm{Ca}_{2} \mathrm{SiO}_{4}$. The results from high-resolution laboratory X-ray powder diffraction have 
revealed that the oxygen variable samples can be prepared but the fixed oxygen content series is not stabilized. Electrochemical characterization allowed us to establish the nature of conductivity.

\section{Material and methods}

\subsection{Synthesis-sintering conditions.}

Two silicate series have been prepared: i) $\mathrm{Ca}_{2}\left(\mathrm{SiO}_{4}\right)_{1-2 \mathrm{x}}\left(\mathrm{Al}_{2} \mathrm{O}_{7}\right)_{\mathrm{x}} \square_{\mathrm{x}}(\mathrm{x}=0,0.010,0.014,0.03)$, hereafter labelled as $\mathrm{Ca}_{2} \mathrm{Si}_{1-2 \mathrm{x}} \mathrm{Al}_{2 \mathrm{x}} \mathrm{O}_{4-\mathrm{x}} \square_{\mathrm{x}}\left(\mathrm{Ca}_{2} \mathrm{Al}_{2 \mathrm{x}}\right)$ and ii) $\mathrm{Ca}_{2-\mathrm{x}} \mathrm{Al}_{\mathrm{x}}\left(\mathrm{SiO}_{4}\right)_{1-\mathrm{x}}\left(\mathrm{AlO}_{4}\right)_{\mathrm{x}},(\mathrm{x}=0.03$ and 0.05) hereafter labelled as $\mathrm{Ca}_{2-\mathrm{x}} \mathrm{Al}_{\mathrm{x}} \mathrm{Si}_{1-\mathrm{x}} \mathrm{Al}_{2 \mathrm{x}} \mathrm{O}_{4}\left(\mathrm{Ca}_{2-\mathrm{x}} \mathrm{Al}_{2 \mathrm{x}}\right)$. These compounds were synthesized by reaction sintering using high purity oxides and carbonates as starting materials: $\mathrm{CaCO}_{3}(99.95 \%$ $100.05 \%$ from Alfa Aesar), $\mathrm{SiO}_{2}$ (99.7\% from $\mathrm{ABCR}$ ) and $\gamma-\mathrm{Al}_{2} \mathrm{O}_{3}$ (99.999\% from Alfa Aesar). Raw mixtures were ground in a Fritsch ball mill (model Pulverisette $7,45 \mathrm{~cm}^{3}$ agate vessel containing 7 agate balls with a diameter of $15 \mathrm{~mm}$ ) during $30 \mathrm{~min}$ at $200 \mathrm{rpm}$ with reverse rotation each $10 \mathrm{~min}$ and preheated at $1050^{\circ} \mathrm{C}$ for 4 hours (heating rate of $10^{\circ} \mathrm{C} \cdot \mathrm{min}^{-1}$ ) in order to prepared 5 g of each sample. Under these conditions, only partial reaction takes place. The resulting powders were reground in a planetary ball mill, pelletized (10 mm diameter, $\sim 1 \mathrm{~mm}$ of thickness, $500 \mathrm{MPa})$ and a second thermal treatment was carried out at $1500{ }^{\circ} \mathrm{C}$ for 6 hours (heating rate of $10^{\circ} \mathrm{C} \cdot \mathrm{min}^{-1}$ ) before being slowly cooled (thermal dissipation). Compaction was calculated taking into account the pellet mass, volume and the crystallographic density. Three pellets were prepared under identical experimental conditions: one (after grinding) for the diffraction study, a second one for impedance characterization, and a third one for the microstructure characterization.

\subsection{X-ray powder diffraction.}

All compounds were characterized by laboratory X-ray powder diffraction (LXRPD) at room temperature. The powder patterns were collected on a PANalytical X'Pert Pro MPD automated diffractometer (PANalytical) equipped with a $\mathrm{Ge}(111)$ primary monochromator and the $\mathrm{X}^{\prime}$ Celerator detector. The overall measurement time was approximately $4 \mathrm{~h}$ per pattern to have good statistics over the 10 to $140^{\circ}(2 \theta)$ angular range, with $0.017^{\circ}$ step size. Structural analyses were performed using GSAS suite of programs. ${ }^{39}$ Final global optimized parameters were: background coefficients, zero-shift error, cell parameters and peak shape parameters using a pseudo-Voigt function ${ }^{40}$ corrected for axial divergence. ${ }^{41}$

\subsection{Thermal analysis.}


Thermogravimetric analysis (TGA) data were recorded on a SDT-Q600 analyzer from TA instruments (New Castle, DE). The temperature was varied from RT to $1000{ }^{\circ} \mathrm{C}$ at a heating/cooling rate of $5{ }^{\circ} \mathrm{C} \cdot \mathrm{min}^{-1}$. Different heating/cooling cycles were carried out to study the thermal reversibility and reproducibility of the measurements. Measurements were carried out on samples in open platinum crucibles under a mixture flow of dry-air $(10 \mathrm{~mL} / \mathrm{min})$ and wet-air $(15 \mathrm{~mL} / \mathrm{min})$ saturated by bubbling in water at $20^{\circ} \mathrm{C}$.

\subsection{Microstructural characterization and conductivity measurements.}

The microstructure of the ceramics was observed by scanning electron microscope (SEM) (Jeol JSM-6490LV) combined with energy dispersive spectroscopy (EDS). Platinum electrodes were made by coating opposite pellet faces with METALOR ${ }^{\circledR} 6082$ platinum ink and heating to $800{ }^{\circ} \mathrm{C}$ at a rate of $5^{\circ} \mathrm{C} \cdot \mathrm{min}^{-1}$ for $15 \mathrm{~min}$ in air to decompose the paste and to harden the Pt residue. Impedance spectra were obtained using a frequency response analyzer (Solartron 1260) in different dry and wet gases $\left(\mathrm{N}_{2}, \mathrm{O}_{2}\right)$ in the $0.1 \mathrm{~Hz}$ to $1 \mathrm{MHz}$ frequency range with an ac perturbation of 100 $\mathrm{mV}$. The spectra were recorded upon cooling from 900 to $500{ }^{\circ} \mathrm{C}$ with a stabilization time of 10 minutes between consecutive measurements. Impedance spectra were analyzed with ZView program. ${ }^{42}$ The resistance and capacitance values of the different contributions were obtained by fitting the impedance spectra data with equivalent circuits. The equivalent circuit consisted of $(R Q)$ elements in series, where $R$ is a resistance and $Q$ is a pseudocapacitance in parallel.

The overall conductivity as a function of oxygen partial pressure $\left[p\left(\mathrm{O}_{2}\right)\right.$ from air to $\sim 10^{-20}$ atm $]$ were performed in a closed tube furnace cell. The $p\left(\mathrm{O}_{2}\right)$ values were monitored by using a YSZ oxygen sensor, placed next to the pellet in the cell. The conductivity was continuously recorded as a function of $p\left(\mathrm{O}_{2}\right)$. The process consisted on flushing the system with dry $5 \% \mathrm{H}_{2}-\mathrm{Ar}$ gas mixture at 900 to reach a minimum in oxygen activity inside the furnace and to ensure that the sample was close to the equilibrium. Then, the gas flow was switched off and the oxygen partial pressure slowly recovers to atmospheric pressure by free diffusion, since the system is not fully airtight. The isothermal cycle took over $48 \mathrm{~h}$ to complete.

2.5. ${ }^{27}$ Al Magic Angle Spinning Nuclear Magnetic Resonance (MAS NMR).

${ }^{27} \mathrm{Al}$ MAS-NMR spectra were recorded in an Avance-400 Bruker spectrometer. The resonance frequency was 104.2 MHz (B0=9.4 T). Spectra were recorded using $\pi / 2(2 \mu \mathrm{s})$ pulses and spinning rate of $10 \mathrm{kHz}$. The number of accumulations was 64 and intervals between accumulations 10s. Chemical shift of NMR signals are given relative to an aqueous solution $\mathrm{AlCl}_{3}(1 \mathrm{M})$. 


\section{Results and discussion}

\subsection{Single phase existence ranges.}

Reaction sintering is a particular type of sintering process in which both chemical reaction of starting compounds and densification are achieved simultaneously in a simple heating step. It has been employed to simplify the processing of the ceramic pellets. After sintering, the pellet were ground and studied by LXRPD and their patterns were analyzed by the Rietveld method using the structural description reported by Mumme et al. ${ }^{43}$, for $\beta$-form. Concerning $\mathrm{Ca}_{2} \mathrm{Si}_{1-2 \mathrm{x}} \mathrm{Al}_{2 \mathrm{x}} \mathrm{O}_{4-\mathrm{x}} \square_{\mathrm{x}}$ $\mathrm{Ca}_{2} \mathrm{Al}_{2 \mathrm{x}}$ family, the dominant phase under our synthetic conditions was the $\beta-\mathrm{C}_{2} \mathrm{~S}$, see Figure 2 . Two secondary minor phases, $\mathrm{Ca}_{3} \mathrm{Al}_{2} \mathrm{O}_{6}$ (PDF 70-0839; ICSD 1841) and $\gamma-\mathrm{C}_{2} \mathrm{~S}$ (PDF 01-086-0397; ICSD 200707) were observed at higher and lower x values, respectively. It is important to underline that this thermo-mechanical treatments at high temperature ensure the absence of free lime, $\mathrm{CaO}$, showing that the reaction was completed. Rietveld refinements were performed by refining only the overall parameters and weight fractions of all the phases. Atomic parameters were not optimized as final Rietveld disagreement factors were low enough, $\mathrm{R}_{\mathrm{F}} \sim 2 \%$. As an example of the refinement qualities, the Rietveld plot of $\mathrm{Ca}_{2} \mathrm{Al}_{0.028}$ is shown in Figure 3. Table 1 gives weight fractions of side phases as well as the refined unit cell volumes of the series. The volume increases along the series, as expected, as $\mathrm{Al}^{3+}$ has a larger ionic radius than that of $\mathrm{Si}^{4+}$. This result confirms the partial substitution of silicon by aluminum. From the modifications observed in the powder patterns, Figure 2, it is clear that aluminum is being incorporated into the belite structure with a concomitant oxide vacancies formation. In any case, the compositional limit of the series must be close to $\mathrm{x}=0.014$ under the reported synthetic conditions. ${ }^{27} \mathrm{Al}$ MAS NMR spectra for $\mathrm{Ca}_{2} \mathrm{Al}_{0.028}$ sample is shown in the inset of Figure 2. The band located close to $\sim-70 \mathrm{ppm}$ is ascribed to tetrahedral environments, ${ }^{44} \mathrm{Al}$ with pentahedral or octahedral coordination is absent in this sample.

All attempts to synthesize $\mathrm{Ca}_{2-\mathrm{x}} \mathrm{Al}_{\mathrm{x}} \mathrm{Si}_{1-\mathrm{x}} \mathrm{Al}_{2 \mathrm{x}} \mathrm{O}_{4}\left(\mathrm{Ca}_{2-\mathrm{x}} \mathrm{Al}_{2 \mathrm{x}}\right)$ compounds by solid state reaction were unsuccessful; even high values of aluminium were not able to warn the formation of $\gamma-C_{2} S$. The presence of this phase was confirmed, in addition to the powder diffraction study, as after the reaction sintering process the pellets became powder. Consequently, this series was not further characterized.

These results indicates that aluminium can be incorporated within the framework of dicalcium silicate and stabilize the $\beta$-form only by replacing the silicate units and forming vacancies. There were not evidences to support the partial substitution of calcium by aluminium. This mechanism of stabilization of high temperature polymorphs of belite is completely different from that established 
for tricalcium silicate, in which aluminium substitutes both calcium and silicon to stabilize the high temperature polymorphs, without the formation of oxygen vacancies. Theoretical studies are needed to explain the different mechanisms of Aluminium doping in alite and belite.

\subsection{Termogravimetric analysis.}

$\mathrm{Ca}_{2} \mathrm{Si}_{0.972} \mathrm{Al}_{0.028} \mathrm{O}_{3.986} \square_{0.014}$ and $\mathrm{Ca}_{1.85} \mathrm{Na}_{0.15}\left(\mathrm{SiO}_{4}\right)_{0.85}\left(\mathrm{BO}_{3}\right)_{0.15}$ (a related sample ${ }^{38}$ without vacancies) were studied by thermogravimetric analysis to evaluate the influence of Al-substitution and the consequent increase of vacancy concentration on the incorporation of water in the structure. Water uptake depends on the available oxygen vacancies in the structure and therefore differences are expected depending on the vacancy contents. The thermogravimetric measurements recorded under humidified air showed reproducible curves on both cooling and heating cycles, see Figure 4.

The trace of $\mathrm{Ca}_{2} \mathrm{Si}_{0.972} \mathrm{Al}_{0.028} \mathrm{O}_{3.986} \square_{0.014}$ shows the typical behavior of a proton conducting material with weight increase upon cooling due to water uptake and the formation of protonic defects, according to the hydration of oxygen vacancies (Eq. 1). For these samples the water uptake increases with the oxygen vacancies content from 0.09 wt\% (0.82 mol\%) for $\mathrm{Ca}_{1.85} \mathrm{Na}_{0.15}$ (no vacancies) to $0.22 \mathrm{wt} \%(2.1 \mathrm{~mol} \%)$ for $\mathrm{Ca}_{2} \mathrm{Al}_{0.028}$ due to the large concentration of oxygen vacancies $(1.4 \mathrm{~mol} \%)$. The higher water content retained respect to the theoretical value is likely due to adsorbed water, in fact, $\mathrm{Ca}_{1.85} \mathrm{Na}_{0.15}$ retains some water and do not have vacancies. These results further confirm that $\mathrm{Al}$ is incorporated in the belite framework with the concomitant oxygen vacancy increase.

\subsection{Electrical characterization}

As mentioned above, the family $\mathrm{Ca}_{2} \mathrm{Al}_{2 \mathrm{x}}$ was used to perform the electrical characterization. The sintering conditions used to prepare the ceramic pellets led to very dense specimens with relative densities $\sim 90 \%$. Weight losses due to possible cation evaporation were not detected during the sintering process. Figure 5 shows the SEM micrograph obtained for a representative sintered pellet with composition $\mathrm{Ca}_{2} \mathrm{Al}_{0.028}$. The pellet exhibits low porosity and no indications of liquid phase formation or phase segregation at the grain boundaries were observed.

In order to establish the existence of mixed ionic oxide-proton conductivity in the $\mathrm{Ca}_{2} \mathrm{Si}_{1-2 \mathrm{x}} \mathrm{Al}_{2 \mathrm{x}} \mathrm{O}_{4}$ -

${ }_{\mathrm{x}} \square_{\mathrm{x}}$ series, an impedance spectroscopy study under a constant flow of dry and wet $\mathrm{N}_{2}$ and $\mathrm{O}_{2}$ gases was carried out. All impedance spectra show two separated contributions at high temperature ascribed to grain interior and electrode processes, Figure 6 . They were fitted by using the following equivalent circuit: $\left(R_{b} Q_{b}\right) Q_{e}$, where the subscripts $b$, and $e$ denote grain interior and electrode 
processes respectively. The resistance of bulk contribution decreases with increasing the water partial pressure, which confirms the existence of proton conduction in this material.

Figure 7 shows the Arrhenius plots of overall conductivity for the $\mathrm{Ca}_{2} \mathrm{Si}_{0.972} \mathrm{Al}_{0.028} \mathrm{O}_{3.986} \square_{0.014}$ sample under different atmospheres. It is clear from that figure that the conductivity in wet atmospheres is always higher than in dry conditions in the whole studied temperature range, supporting that the sample exhibits proton conductivity. The total conductivity values for $\mathrm{Ca}_{2} \mathrm{Al}_{0.028}$ at $900{ }^{\circ} \mathrm{C}$ were $2.7 \cdot 10^{-5}$ and $2.5 \cdot 10^{-6} \mathrm{~S} \cdot \mathrm{cm}^{-1}$ in wet $\mathrm{O}_{2}$ and dry- $\mathrm{N}_{2}$, respectively. These values are quite similar to aluminium doped tricalcium oxysilicate: $5.6 \cdot 10^{-5}$ and $8 \cdot 10^{-5} \mathrm{~S} \cdot \mathrm{cm}^{-1}$ for $\mathrm{Ca}_{2.985} \mathrm{Al}_{0.015}\left(\mathrm{Si}_{0.985} \mathrm{Al}_{0.015} \mathrm{O}_{4}\right) \mathrm{O}$ and $\mathrm{Ca}_{2.93} \mathrm{Mg}_{0.07}\left(\mathrm{Si}_{0.98} \mathrm{Al}_{0.02} \mathrm{O}_{4}\right) \mathrm{O}_{0.99} \square_{0.01}$, respectively; although these samples have different crystal structures. ${ }^{13,14}$

On the other hand, the values of conductivity in $\mathrm{N}_{2}$ (dry or wet) are lower than those in $\mathrm{O}_{2}$ (dry or wet), this behavior can be mainly ascribed to the temperature-variation of a small p-type contribution, which develops under oxidizing conditions like in aluminum-doped tricalcium oxysilicate. $^{13,14}$ The Arrhenius plots for all studied compositions fall on a set of approximately parallel lines with activation energies ranging between 1.0 and $1.1 \mathrm{eV}$. These values are close to those previously reported for similar compositions which are typical of mixed proton-oxide conductors. The conductivity in wet $\mathrm{N}_{2}$ is almost one order of magnitude higher than in dry $\mathrm{N}_{2}$; furthermore, this proton contribution is very important even at high temperature. This indicates that a minor fraction of water remains in the structure even at very high temperature under a humidified atmosphere in agreement with thermogravimetric measurements. Figure 7 also displays the conductivity of the related compound $\mathrm{Ca}_{1.85} \mathrm{Na}_{0.15}\left(\mathrm{SiO}_{4}\right)_{0.85}\left(\mathrm{BO}_{3}\right)_{0.15}$ without oxygen vacancies. As it can be observed, Al-substitution enhances significantly the ionic conductivity of these materials above $500^{\circ} \mathrm{C}$ likely due to oxygen vacancies. The ionic conductivity for a pure oxide ion conductor is independent of the oxygen partial pressure in a wide range of $p\left(\mathrm{O}_{2}\right)$ values. However, the conductivity increases for a mixed ionic-electronic conductor as $p\left(\mathrm{O}_{2}\right)$ increases or decreases, depending on the predominant electronic contribution ( $\mathrm{p}$ - and n-type, respectively). The variation of the overall conductivity for $\mathrm{Ca}_{2} \mathrm{Si}_{0.972} \mathrm{Al}_{0.028} \mathrm{O}_{3.986} \square_{0.014}$ sample at $900^{\circ} \mathrm{C}$ as a function of $p\left(\mathrm{O}_{2}\right)$ is shown in the inset of Figure 7.

Several conclusions can be drawn from data displayed in Figure 7. Firstly, at high $p\left(\mathrm{O}_{2}\right)$ range, the conductivity increases slightly with $p\left(\mathrm{O}_{2}\right)$, indicating that the conduction mechanism includes ionic and electron-hole components. Secondly, the ionic plateau values at intermediate oxygen partial pressure indicate pure ion conduction; and thirdly, there is a drop in conductivity at very low reducing conditions. This last behavior has been previously reported and it was interpreted based on 
a decrease in the proton contribution because the oxygen partial pressure is not constant during the experiment. ${ }^{45}$ It must be highlighted that decreasing the oxygen partial pressure induces a lowering in the water partial pressure. This result also indicates that proton contribution in these materials is significant up to $900{ }^{\circ} \mathrm{C}$ and a similar trend has been already reported for other solid electrolytes, $\mathrm{i}$. e. $\mathrm{La}_{2} \mathrm{Zr}_{2} \mathrm{O}_{7}, \mathrm{SrZrO}_{3}, \mathrm{BaCeO}_{3}{ }^{1,45-48}$ and $\mathrm{Ca}_{3} \mathrm{SiO}_{5}$-based materials. ${ }^{13,14}$

\section{Conclusions}

Aluminium is incorporated into the framework of dicalcium silicate and stabilize the $\beta$-form by replacing the silicate units and generating oxygen vacancies, $\mathrm{Ca}_{2} \mathrm{Si}_{1-2 \mathrm{x}} \mathrm{Al}_{2 \mathrm{x}} \mathrm{O}_{4-\mathrm{x}} \square_{\mathrm{x}}$, up to $\mathrm{x} \leq 0.014$. Aluminium substitution at both calcium and silicon sites, $\mathrm{Ca}_{2-\mathrm{x}} \mathrm{Al}_{\mathrm{x}}\left(\mathrm{SiO}_{4}\right)_{1-\mathrm{x}}\left(\mathrm{AlO}_{4}\right)_{\mathrm{x}}$, is not formed, conversely to the aluminium doping in tricalcium oxysilicate. Thermogravimetric measurements collected under humidified air showed reproducible curves on both cooling and heating cycles. For these samples the water uptake increases with the oxygen vacancy content, as expected. The incorporation of $\mathrm{Al}^{3+}$ increases the oxygen vacancy concentration in the structure and enhances the ionic conductivity. The Arrhenius plots fall on a set of approximately parallel lines with activation energies ranging between 1.0 and $1.1 \mathrm{eV}$. These values are typical for mixed proton-oxide conductors. The conductivity in wet $\mathrm{N}_{2}$ is almost one order of magnitude higher than that in dry $\mathrm{N}_{2}$; furthermore, this proton contribution is very important even at very high temperature. This indicates that a minor fraction of water remains in the structure even at very high temperature under a humidified atmosphere. Ionic conductivity measurements as a function of the oxygen partial pressure support proton conductivity and a small p-type electronic contribution under oxidizing conditions.

\section{Acknowledgment}

This work has been supported by Spanish Ministry of Science and Innovation through MAT201015175 research grant which is cofounded by FEDER and by Junta de Andalucía (Spain) through the P10-FQM-6680 research grant.

\section{References}

1 H. Iwahara, H. Uchida, K.Ono and K.J. Ogaki, J. Electrochem. Soc., 1988, 135, 529-533.

2 H. Iwahara, Solid State Ionics, 1996, 86-88, 9-15. 
K.D. Kreuer, Annu. Rev. Res., 2003, 33, 333-359.

4 T. Norby, Solid State Ionics, 1999, 125, 1-11.

$5 \quad$ N. Bonanos, K.S. Knight and B.Ellis, Solid State Ionics, 1995, 79, 161-170.

6 H. Iwahara, T.Yajima and H. Ushida, Solid State Ionics, 1994, 70-71 267-271.

7 D. Shima and S.M.Haile, Solid State Ionics, 1997, 97, 443-455.

8 F.L. Chen, O.Toft Sørensen, G.Y. Meng and D.K. Peng, J. Eur. Ceram. Soc., 1998, 18, 13891395 .

9 N. Bonanos, B. Ellis, K.S. Knight and M.N. Mahmood, Solid State Ionics, 1989, 35, 179-188.

10 G. Ma, T. Shimura and H. Iwahara, Solid State Ionics, 1998, 120, 51-60.

11 A.N. Virkar and H.S. Maiti, J. Power Sources, 1985, 14, 295-303.

12 E. Gorbova, V. Maragou, D. Medvedev, A. Demin and P. Tsiakaras, J. Power Sources, 2008, 181, 207-213.

13 J.M. Porras-Vázquez, A. G. De la Torre, D. Marrero-López, E.R. Losilla and M.A.G. Aranda, Dalton Trans., 2006, 22, 2691-2697.

14 J.M. Porras-Vázquez, A.G. De la Torre, E.R. Losilla and M.A.G. Aranda, Solid State Ionics, 2007, 178, 1073-1080.

15 G. Álvarez-Pinazo, A. Cuesta, M. García-Maté, I. Santacruz, E. R. Losilla, A. G. De la Torre, L León-Reina and M. A. G. Aranda, Cem. Concr. Res., 2012, 42, 960-971.

16 S.N. Ghosh, P.B. Rao, A.K. Paul and K.J. Raina, Mater. Sci., 1979, 14, 1554-1566.

17 M. Regourd, M. Bigare, J. Forest, A. Guinier, Proceedings of the $5^{\text {th }}$ International Symposium on the Chemistry of Cement, Part I, Supplement Paper I-10, Tokyo (1968) 44-48.

18 C.M. Midgley, Acta Crystallogr. 1952, 5, 307-312.

19 D.K. Smith, A. Majumdar and F. Ordway, Acta Crystallogr. 1965, 18, 787-795.

20 R. Czaya, Acta Crystallogr. Sect. B, 1971, B 27, 848-849.

21 S. Udagawa, K. Urabe, M. Natsume and T. Yano, Cem. Concr. Res., 1980, 10, 139-144.

22 K.H. Jost, B. Ziemer and R. Seydel, Acta Crystallogr. Sect. B, 1977, B 33, 1696-1700.

23 K. Susuki and G. Yamaguchi, Proceedings of the $5^{\text {th }}$ International Symposium on the Chemistry of Cement, Supplement Paper, Tokyo (1968) 67-72.

24 Y.J. Kim, I. Nettleship and W.M. Kriven, J. Am. Ceram. Soc., 1992, 75, 2407-2419.

25 H.F.W. Taylor, Cement Chemistry, Thomas Telford, London, 1997.

26 N.A. Yamnova, N.V. Zubkova, N.N. Eremin, A. E. Zadov and V. M. Gazeev , Crystallography Reports 56 No. 2, 2011, 210-220.

27 H. Manzano, E. Durgun, M.J. Abdolhosseine Qomi, F.-J., Roland J.M. Pellenq and J.C. Grossman, Chem. Mater., 2012, 24, 1262-1267. 
28 E. Durgun, H. Manzano, R.J.M. Pellenq and J.C. Grossman, Chem. Mater., 2012, 24, 12621267.

29 Y.M. Kim and S.H. Hong, J. Am. Ceram. Soc., 2004, 87, 900-905.

30 I. Jelenic, A. Bezjak and M. Bujan, Cem. Concr. Res., 1978, 8, 173-180.

31 M. Pritts and K.E. Daugherty, Cem. Concr. Res., 1976, 6, 783-796.

32 D.L. Kantro and C.H. Weise, J. Am. Ceram. Soc., 1979, 62, 621-626.

33 B. Matkovic, V. Carin, T. Gacesa, R. Halle and I. Jelenic, Am. Ceram. Soc. Bull., 1981, 60, $825-829$.

34 P. Fierens and J. Tirlocq, Cem. Concr. Res., 1983, 13, 267-276.

35 B. Ziemer, B. Altrichter and V. Jesenak, Cem. Concr. Res., 1984, 14, 686-692.

36 My. Y. Benarchid, A. Diouri, A. Boukhari, J. Aride, J. Rogez and R. Kastanet, Cem. Concr. Res., 2004, 34, 1873-1879.

37 G-C. Lai, T. Nojiri and K-I. Nakano, Cem. Concr. Res., 1992, 22, 743-754.

38 A. Cuesta, E. R. Losilla, M. A. G. Aranda, J. Sanz and Á. G. de la Torre, Cem. Concr. Res., 2012, 42, 598-606.

39 A.C. Larson and R.B. Von Dreele, General Structure Analysis System (GSAS) program. Rep. No. LA-UR-86748, Los Alamos National Laboratory, Los Alamos, CA, 1994.

40 P. Thompson, D.E. Cox and J.B. Hasting, J. Appl. Cryst., 1987, 20, 79-83.

41 L.W. Finger, D.E. Cox and A.P. Jephcoat, J. Appl. Cryst., 1994, 27, 892-900.

42 D. Johnson, ZView: a Software Program for IES Analysis, Version 2.8, Scribner Associates, Inc. Southern Pines, NC, 200.

43 W. G. Mumme, R.J. Hill, G. Bushnell-Wye and E.R.N. Seegnit, N. Jb. Miner Abh., 1995, 169, $35-68$.

44 J. Sanz and J.M. Serratosa, J. Am. Chem. Soc., 1984, 106, 4790-4793.

45 J.A. Labrincha, F.M.B. Marques and J.R. Frade, Mater. Sci., 1995, 30, 2785-2792.

46 J.A. Labrincha, J.R. Frade and F.M.B. Marques, Solid State Ionics, 1997, 99, 33-40.

47 J.A. Labrincha, J.R. Frade and F.M.B Marques, Solid State Ionics, 1993, 61, 71-75.

48 T. Yamija, H. Susuki, T.Yogo and H. Iwahara, Solid State Ionics, 1992, 51, 101-107. 


\section{Figure Captions}

Figure 1. Polymorphic transformations of stoichiometric $\mathrm{Ca}_{2} \mathrm{SiO}_{4}$ with temperature.

Figure 2. LXRPD patterns for $\mathrm{Ca}_{2} \mathrm{Si}_{1-2 \mathrm{x}} \mathrm{Al}_{2 \mathrm{x}} \mathrm{O}_{4-\mathrm{x}} \square_{\mathrm{x}}(\mathrm{x}=0,0.010,0.014$ and 0.03$)$ nominal series. Symbols highlight diagnostic peaks for $\gamma-\mathrm{C}_{2} \mathrm{~S}$ (square) and $\mathrm{C}_{3} \mathrm{~A}$ (circle). The inset shows ${ }^{27} \mathrm{Al}$ MAS NMR spectrum for $\mathrm{Ca}_{2} \mathrm{Si}_{0.972} \mathrm{Al}_{0.028} \mathrm{O}_{3.986} \square_{0.014}$.

Figure 3. Rietveld plots, [observed data (crosses), calculated pattern (full line), and difference curve (bottom)] for $\mathrm{Ca}_{2} \mathrm{Si}_{0.972} \mathrm{Al}_{0.028} \mathrm{O}_{3.986} \square_{0.014}$ sample.

Figure 4. Thermogravimetric curves for $\mathrm{Ca}_{2} \mathrm{Si}_{0.972} \mathrm{Al}_{0.028} \mathrm{O}_{3.986} \square_{0.014}$ and $\mathrm{Ca}_{1.85} \mathrm{Na}_{0.15}\left(\mathrm{SiO}_{4}\right)_{0.85}\left(\mathrm{BO}_{3}\right)_{0.15}$ samples performed under humidified air from 400 to $1000{ }^{\circ} \mathrm{C}$.

Figure 5. SEM micrograph of the surface of $\mathrm{Ca}_{2} \mathrm{Si}_{0.972} \mathrm{Al}_{0.028} \mathrm{O}_{3.986} \square_{0.014}$ sintered at $1500{ }^{\circ} \mathrm{C}$ for $4 \mathrm{~h}$.

Figure 6. Impedance spectra for $\mathrm{Ca}_{2} \mathrm{Si}_{0.972} \mathrm{Al}_{0.028} \mathrm{O}_{3.986} \square_{0.014}$ sample under different atmospheres at $800{ }^{\circ} \mathrm{C}$. Inset shows a magnification area.

Figure 7. Arrhenius plots of the total conductivity for $\mathrm{Ca}_{2} \mathrm{Si}_{0.972} \mathrm{Al}_{0.028} \mathrm{O}_{3.986} \square_{0.014}$ under various atmospheres. The conductivity of the related compound $\mathrm{Ca}_{1.85} \mathrm{Na}_{0.15}\left(\mathrm{SiO}_{4}\right)_{0.85}\left(\mathrm{BO}_{3}\right)_{0.15}$ is also included for the sake of comparison (the sample was prepared as reported in [35]). The inset shows overall conductivity data at $900^{\circ} \mathrm{C}$ as a function of oxygen partial pressure for $\mathrm{Ca}_{2} \mathrm{Si}_{0.972} \mathrm{Al}_{0.028} \mathrm{O}_{3.986} \square_{0.014}$. 
Table 1. Refined unit cell parameters and Rietveld disagreement factors for $\mathrm{Ca}_{2}\left(\mathrm{SiO}_{4}\right)_{1-2 \mathrm{x}}\left(\mathrm{Al}_{2} \mathrm{O}_{7}\right)_{\mathrm{x}} \square_{\mathrm{x}}(\mathrm{x}=0,0.010,0.014$ and $0.030)$ series. Weight fractions of side phases deduced from Rietveld refinements are also included.

\begin{tabular}{|c|c|c|c|c|c|c|c|c|}
\hline & $\mathrm{a}(\AA \hat{)})$ & $\mathrm{b}(\AA)$ & $\mathrm{c}(\AA \hat{)})$ & $\beta\left({ }^{\circ}\right)$ & $\mathrm{V}\left(\AA^{3}\right)$ & $\mathrm{R}_{\mathrm{wp}}(\%)$ & $\mathrm{R}_{\mathrm{F}}(\%)$ & $\beta-\mathrm{C}_{2} \mathrm{~S} / \gamma-\mathrm{C}_{2} \mathrm{~S} / \mathrm{C}_{3} \mathrm{~S}$ (wt $\left.\%\right)$ \\
\hline $\mathrm{Ca}_{2} \mathrm{Al}$ & $5.5123(1)$ & $7562(1)$ & $9.3181(1)$ & $94.554(1)$ & $345.93(1)$ & 7.8 & 2.0 & $88.7(1) / 11.3(1) /-$ \\
\hline $\mathrm{Ca}_{2} \mathrm{~A}$ & $5.5130(1)$ & $6.7579(1)$ & $9.3233(1)$ & $94.506(1)$ & $346.27(1)$ & 8.0 & 1.8 & $97.8(1) / 2.2(1) /-$ \\
\hline $\mathrm{Ca}_{2} \mathrm{Al}_{0.028}$ & $5.5127(1)$ & $6.7586(1)$ & $9.3266(2)$ & 94.505 & $346.42(2)$ & 9.6 & 2. & $99.0(1) / 1.0(1) /-$ \\
\hline $\mathrm{Ca}_{2} \mathrm{Al}_{0.060}$ & $5.5115(1)$ & $6.7577(2)$ & $9.3299(2)$ & $94.474(1)$ & $346.44(2)$ & 9.4 & 1.9 & $96.5(1) /-/ 3.5(1)$ \\
\hline
\end{tabular}




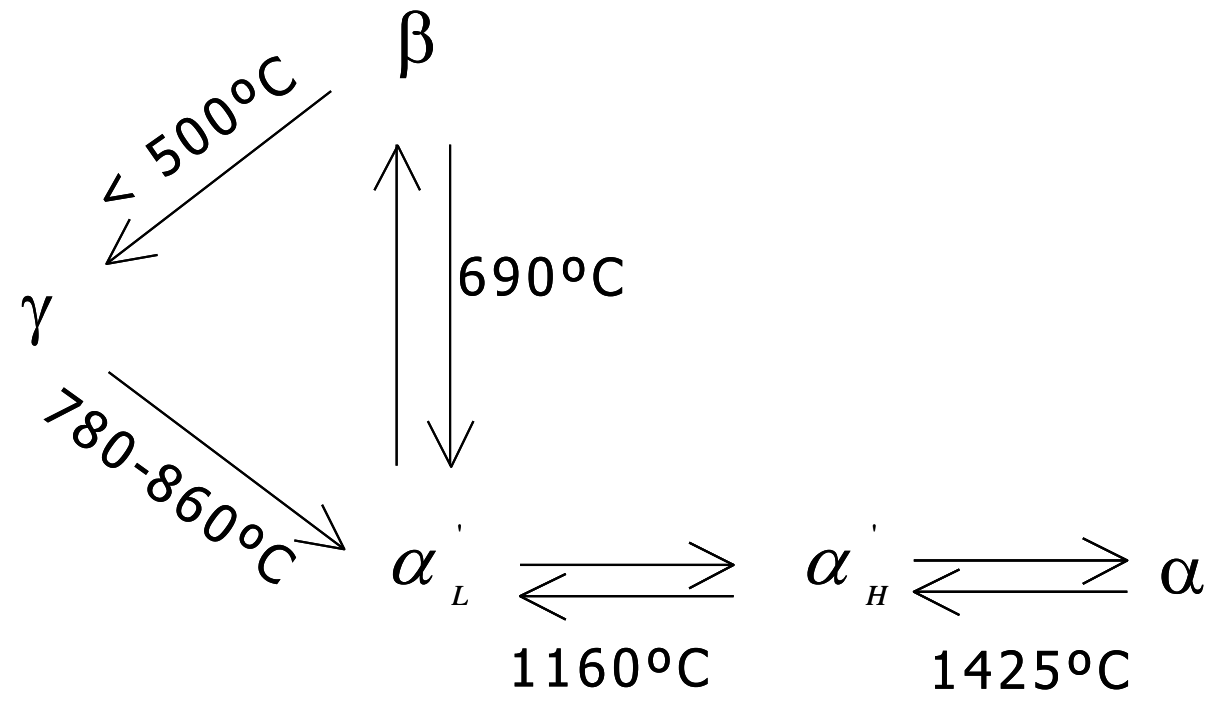

Figure 1 


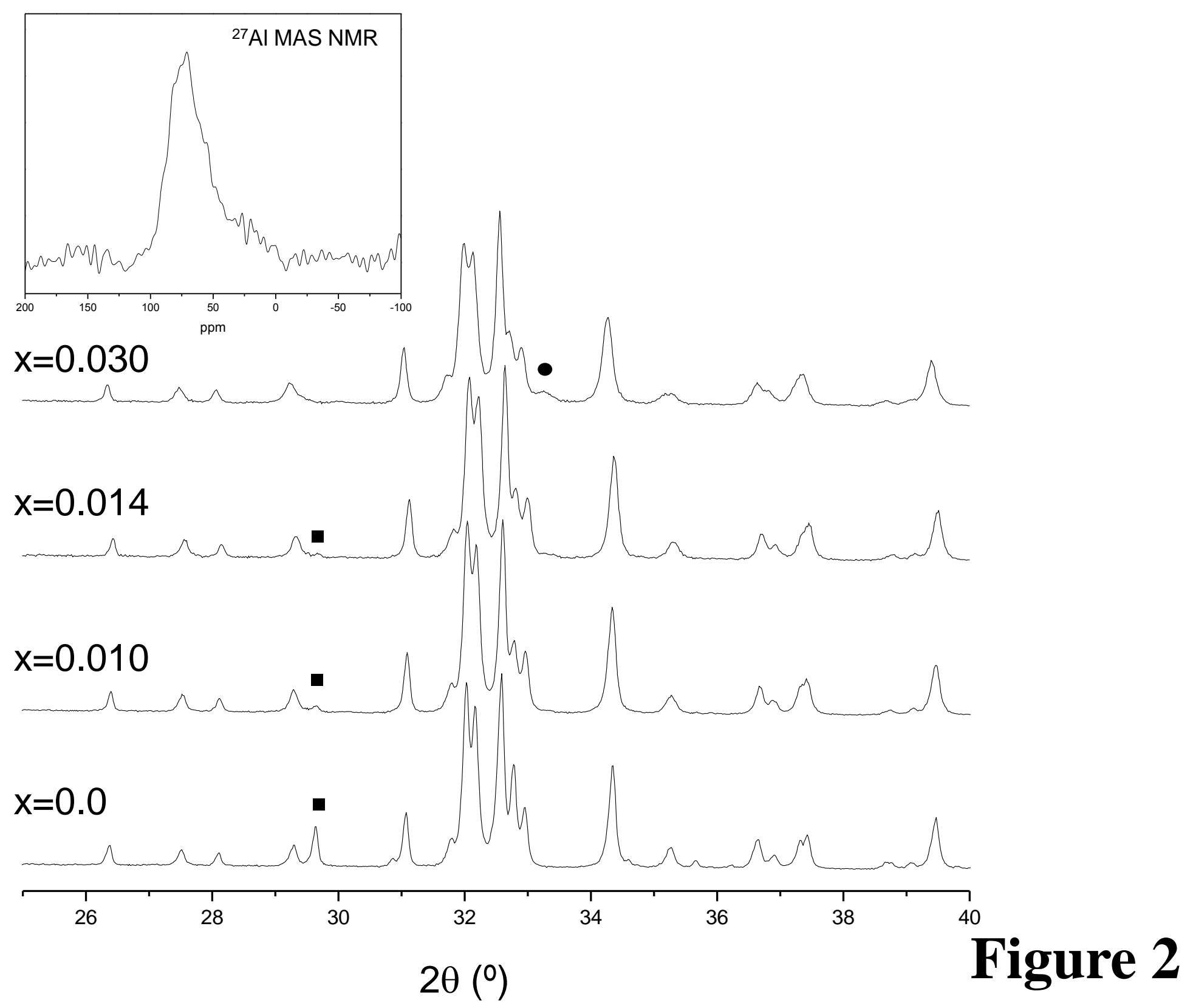




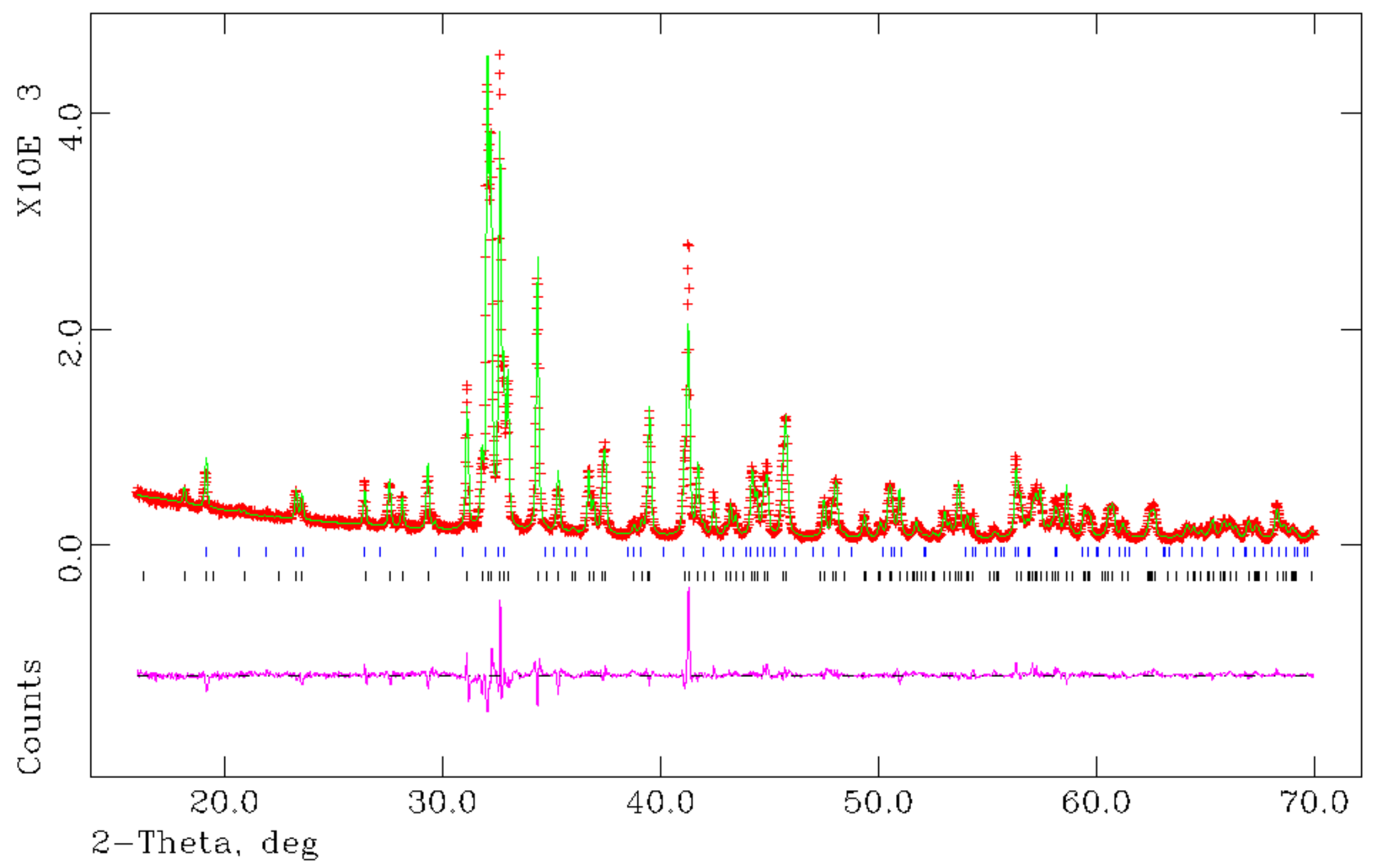

Figure 3 


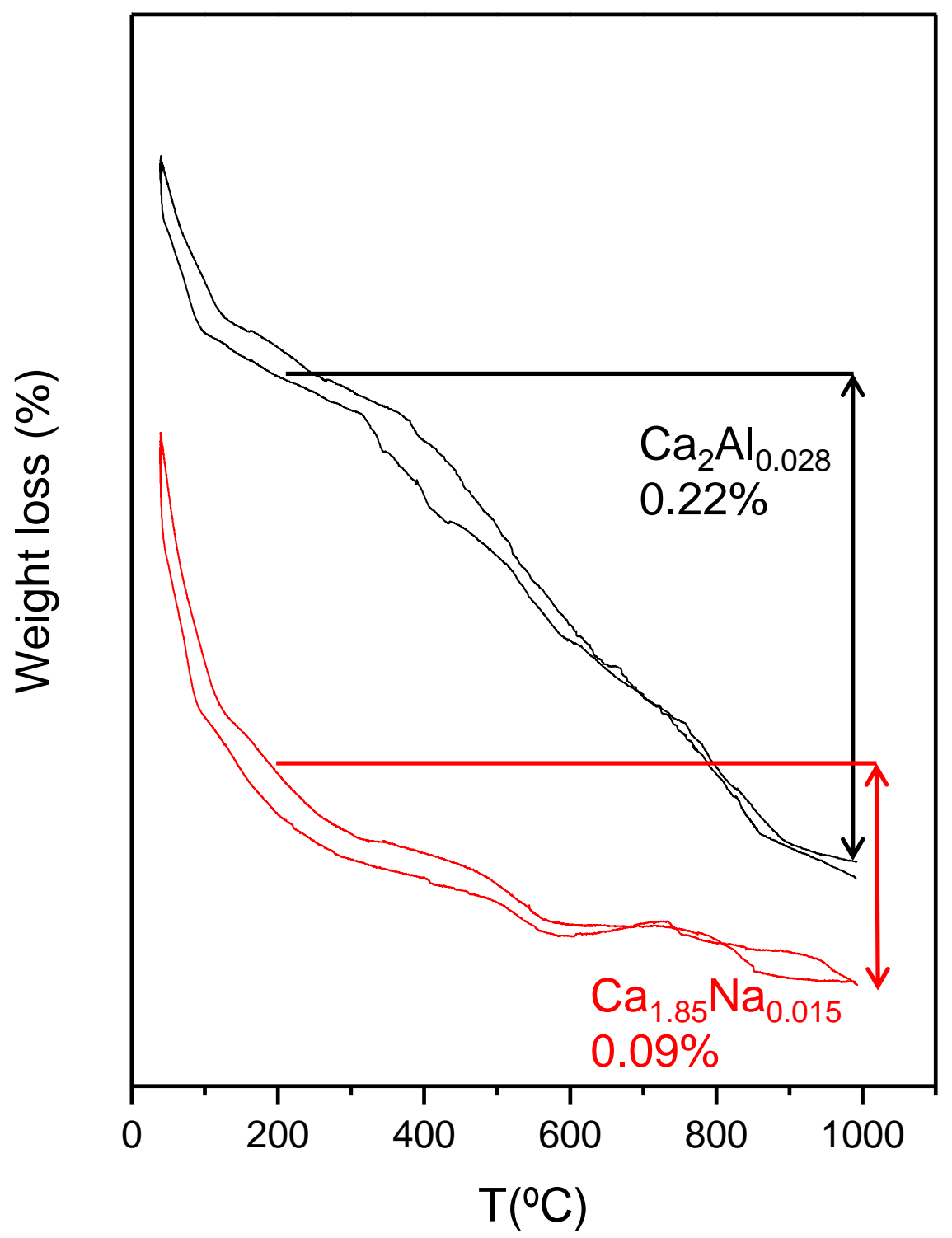

Figure 4 

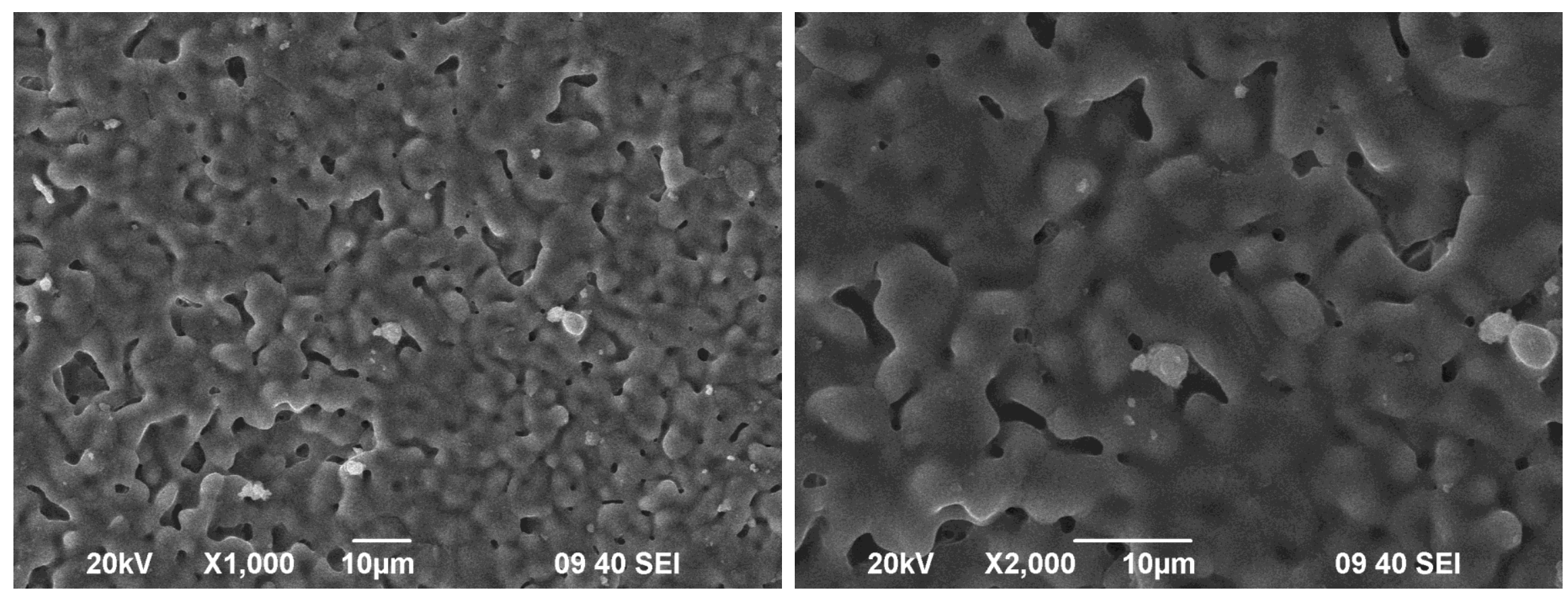

Figure 5 


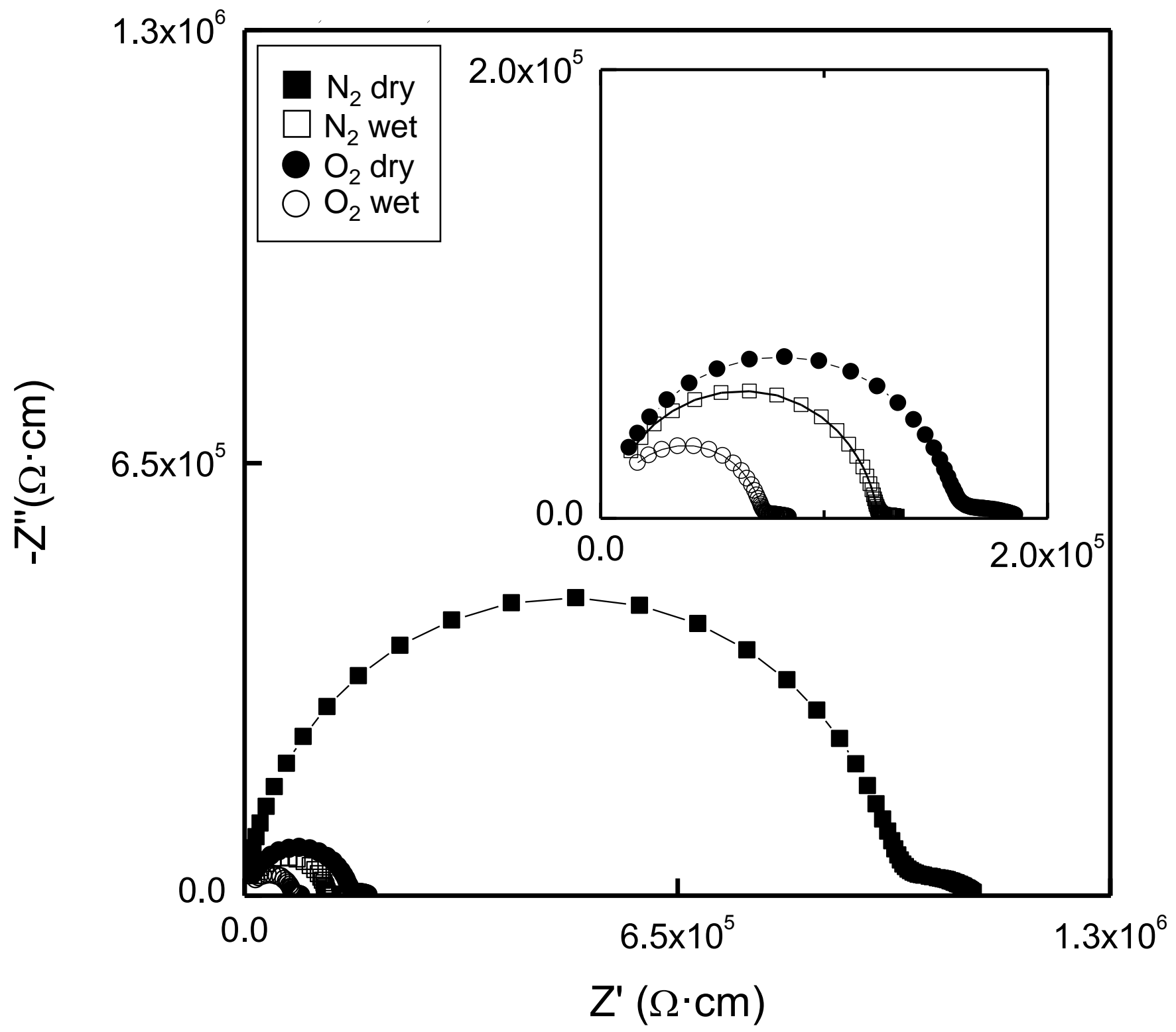

Figure 6 


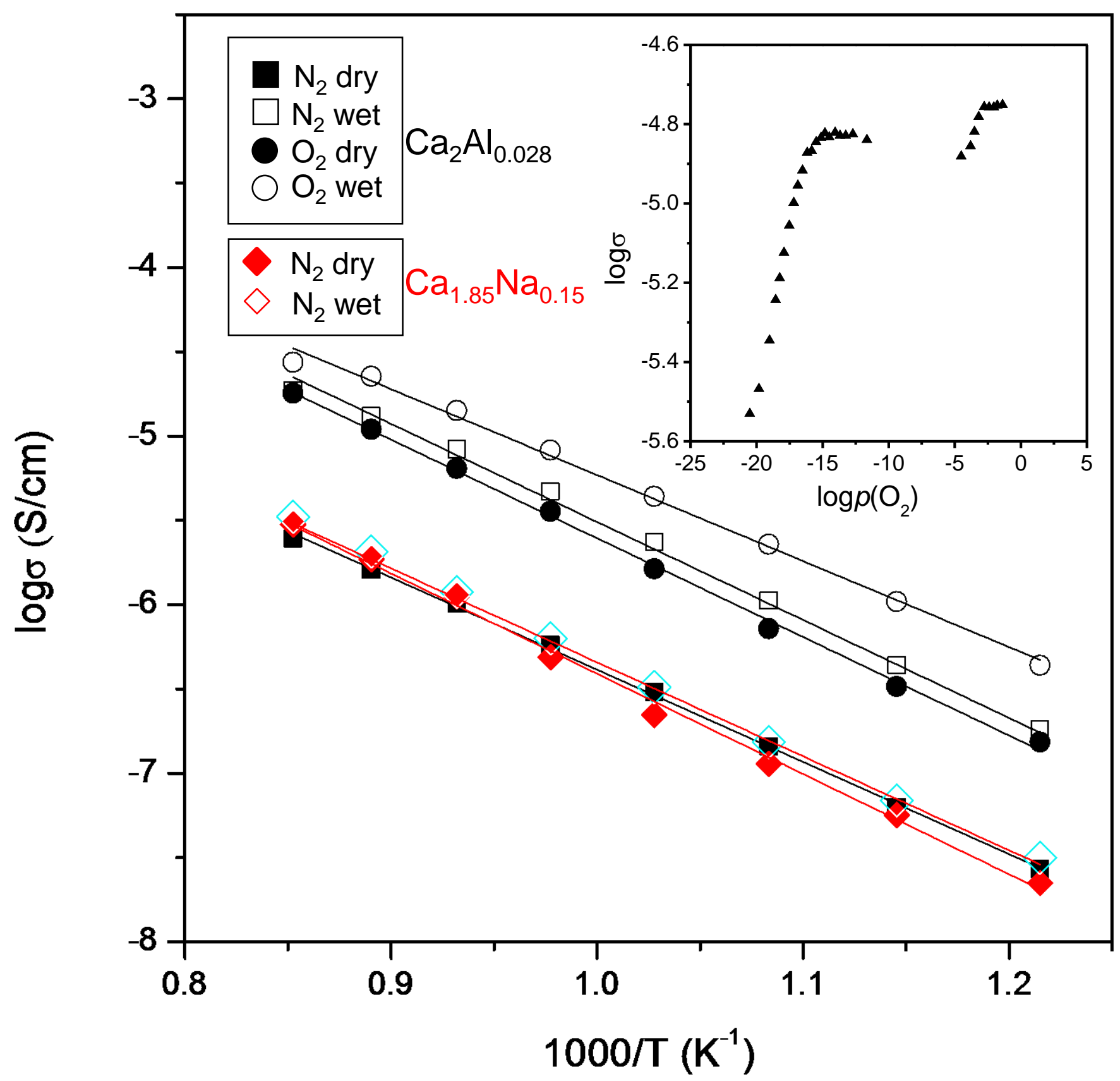

Figure 7 